\title{
SISTEM KEPENDUDUKAN DESA BERBASIS WEB PADA DESA CIHUNI KECAMATAN PAGEDANGAN KABUPATEN TANGERANG
}

\author{
Angelina Efrida Purba ${ }^{1}$, Catur Putro Utomo ${ }^{2}$, Nurjamin ${ }^{3}$ \\ Dosen STMIK Raharja Tangerang ${ }^{1,2}$, Mahasiswa STMIK Raharja ${ }^{3}$ \\ Jl. Jendral Sudirman No. 40, Modernland, Tangerang ${ }^{1,2,3}$ \\ email: angelia.efrida@raharja.info ${ }^{1}$,catur.putro@raharja.info ${ }^{2}$.info,nurjamin@ raharja.info ${ }^{3}$
}

\begin{abstract}
Abstrak
Perkembangan sistem komputerisasi tidak lepas dari perkembangan teknologi yang dapat mempengaruhi banyak aspek kehidupan manusia. Salah satu kelebihan dari sistem komputerisasi ialah menghasilkan sistem yang relevan, tepat waktu dan akurat. Membangun suatu sistem kependudukan desa memerlukan pemahaman yang baik dan jelas mengenai sistem yang akan digunakan baik dalam prosedur sistem, input, output maupun hal-hal yang mempengaruhi kinerja sistem baik untuk jangka pendek maupun jangka panjang. Salah satunya di data kependudukan. Pada Kelurahan desa cihuni yang dilakukan saat ini dengan menggunakan sistem manual. Contoh seperti data kependudukan. Sehingga sering terjadi kesalahan dalam mengolah atau mendata penduduk, dikarenakan dalam pengolahanya masih dengan proses yang konvensional. maka diusulkan untuk membangun sebuah aplikasi dalam bentuk system kependudukan yang dapat digunakan oleh staf desa dalam mengolah semua data kependudukan berbasis web. Diharapkan aplikasi ini dapat membantu selain mengolah data kependudukan juga dapat menyimpan data-data dengan baik dan mempermudah masyarakat dalam hal kebutuhan pelayanan Surat Pengantar.
\end{abstract}

Kata kunci : Web,Kependudukan.

\begin{abstract}
The development of computerized systems can not be separated from technological developments which can affect many aspects of human life. One of the advantages of the computerized system is to produce a system that is relevant, timely and accurate. Build a village settlement system requires a good understanding and clear about the system to be used both in the procedures of the system, input, output and the things that affect system performance both for short term and long term. One of them in the population data. In the village Village Cihuni done today by using a manual system. Examples such as demographic data. So frequent errors in process or keep a record of the population, because in pengolahanya still with the conventional process. it is proposed to build an application in the form of settlement system that can be used by the village staff to process all web-based demographic data. It is expected that these applications can help in addition to demographic data processing can also store data properly and facilitate the public in terms of service needs Letter.
\end{abstract}

Keywords : Web, Population

\section{PENDAHULUAN}

Sejalan dengan berkembangnya ilmu pengetahuan dan teknologi, serta dalam memasuki era globalisasi maka perkembangan di bidang komunikasi pun tidak dapat dihindari, dan kebutuhan manusia di bidang komunikasi semakin besar dan semakin luas, tidak terbatas pada suatu daerah saja. Sarana komunikasi yang ditawarkan pun sangatlah banyak dan memberikan kebebasan bagi masyarakat untuk memilih jenis komunikasi. Sistem Kependudukan Desa 
Berbasis Web Pada Desa Cihuni Kecamatan Pagedangan Kabupaten Tangerang adalah salah satu sarana yang mempermudah petugas pencatat data penduduk di desa cihuni untuk mendata seluruh penduduk di desa tersebut. Selain itu sistem ini juga akan lebih mempermudah masyarakat dalam hal kebutuhan pelayanan Surat Pengantar. Adapun permasalahan lain yang terjadi pada layanan Kantor Desa Cihuni tersebut yaitu yang masih sering terjadi kesalahan dalam mengolah atau mendata penduduk, dikarenakan dalam pengolahanya masih dengan proses yang konvensional.

Dengan sistem yang masih seperti itu tentunya masih banyak sekali kekurangan atau kelemahan yang ditemukan. Kekurangan itu seperti halnya pada saat akan membuat laporan jumlah penduduk harus mereka satu persatu secara manual dari masing-masing buku tentang peristiwa mutasi penduduk. Kelemahan berikutnya adalah pada saat input data penduduk ke dalam surat harus memasukkan satu persatu tentang data penduduk tersebut berdasarkan kartu identitas yang dibawa penduduk yang bersangkutan. Dikantor Desa Cihuni sudah menggunakan dua komputer untuk kegiatan operasinya atau pencatatan data. Untuk mengolah data-data itu diperlukan suatu program komputer, oleh karena itu penulis mencoba untuk merancang salah satu program aplikasi khusus dalam Sistem Kependudukan Desa Berbasis Web Pada Desa Cihuni Kecamtan Pagedangan Kabupaten Tangerang.

\subsection{Permasalahan}

Adapun permasalahan yang terjadi pada layanan Kantor Desa Cihuni tersebut yaitu yang masih sering terjadi kesalahan dalam mengolah atau mendata penduduk, dikarenakan dalam pengolahanya masih dengan proses yang konvensional. Dengan sistem yang masih seperti itu tentunya masih banyak sekali kekurangan atau kelemahan yang ditemukan. Kekurangan itu seperti halnya pada saat akan membuat laporan jumlah penduduk harus mereka satu persatu secara manual dari masing-masing buku tentang peristiwa mutasi penduduk. Kelemahan berikutnya adalah pada saat input data penduduk ke dalam surat harus memasukkan satu persatu tentang data penduduk tersebut berdasarkan kartu identitas yang dibawa penduduk yang bersangkutan. Dikantor Desa Cihuni sudah menggunakan dua komputer untuk kegiatan operasinya atau pencatatan data.

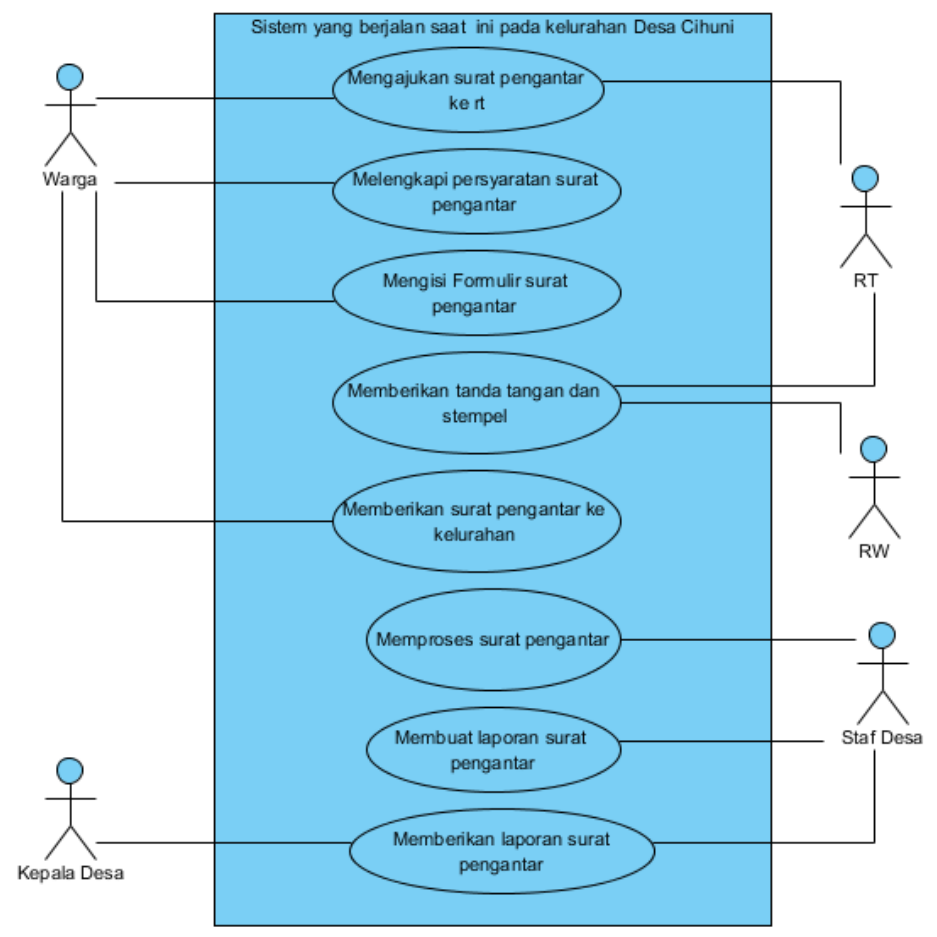

Gambar 1. sistem yang berjalan di kelurahan desa cihui 
Dari gambar diatas, dapat di lihat bahwa untuk menghasilkan suatu aplikasi sistem kependudukan desa berbasis web ,diperlukan system yang dapat membantu staf desa menyimpan data kependudukan desa dengan rapih dan akurat serta mencari data dengan mudah

Dari penjelasan di atas, dapat dirumuskan beberapa permasalahan yaitu sebagai berikut

1. Apakah aplikasi system kependudukan desa berbasis web dapat mendukung sistem yang diterapkan pada Kelurahan desa cihuni ?

2. Bagaimana proses pembuatan aplikasi system kependudukan desa berbasis web?

\section{LANDASAN TEORI}

\subsection{Literature Review}

Banyak penelitian yang sebelumnya dilakukan mengenai system kependudukan desa berbasis web. Dalam upaya pengembangan system kependudukan desa berbasis web ini perlu dilakukan studi pustaka sebagai salah satu dari penerapan metode penelitian yang akan dilakukan. Diantaranya adalah mengidentifikasikan kesenjangan (identify gaps), menghindari pembuatan ulang (reinventing the wheel), mengidentifikasikan metode yang pernah dilakukan, meneruskan penelitian sebelumnya, serta mengetahui orang lain yang spesialisasi dan area penelitiannya sama dibidang ini. Beberapa Literature review tersebut adalah sebagai berikut :

1. Penelitian ini dilakukan oleh Kartika (2012/2013), dengan judul Perancangan Sistem Pendataan Kartu Keluarga Pada Kelurahan Karang Anyar. Ditemukan bahwa sistem yang berjalan pada Kelurahan Karang Anyar masih manual. Dalam pendataan kartu keluarga masih banyak kendala seperti banyak pendaftar yang masih belum mengerti tata cara atau prosedur pembuatan kartu keluarga, maka dari itu penulis merancancang sistem pendataan penduduk yang efektif dan efisien dengan menggunakan bahasa pemrograman php dan tempat penyimpanan data yaitu MySql.

2. Penelitian ini dilakukan oleh Hayadi Hamuda (2012/2013), dengan judul Aplikasi Pengolahan Data Penduduk Berbasis Web pada Kantor Kecamatan Sukadiri Kabupaten Tangerang. ditemukan bahwa padasistem yang berjalan Saat ini Kantor kecamatan Sukadiri masih terdapat sejumlah kekurangan seperti pengolahan data yang belum akurat karena masih menggunakan office 2007, maka dari itu penulis merancang sistem yang dapat menginput akte lahir, edit ktp, input kk dn menampilkan pnduduk. Dengan aplikasi berbasis web menggunakan bahasa pemrogrman php dan media penyimpannya MySql ini diharapkn dapat menciptakan sistem yang efektif dan efisien bagi user.

3. Penelitian ini dilakukan oleh Dwi Priyanti, Siska Iriani (2013), dengan judul Sistem Informasi Data Penduduk Pada Desa Bogoharjo Kecamatan Ngadirojo Kabupaten Pacitan. ditemukan bahwa pada Saat ini Kantor desa Bogoharjo menggunakan sistem informasi secara konvensional yaitu pencatatan data penduduk pada sebuah buku induk yang di sediakan oleh Desa, kemudian direkap kembali untuk membuat laporan penduduk.Sistem yang berjalan mempunyai banyak kekurangan diantaranya memungkinkan adanya kesalahan,membutuhkan waktu yang lama dalam proses pencarian data, maupundalam proses pembuatan laporan. Penelitian ini bertujuan untuk menghasilkan sebuah sistem informasi pengelolaan data penduduk yang lebih cepat, tepat guna, efektif dan efisien pada kantor Desa Bogoharjo.Guna menunjang penelitian ini, metode pengumpulan data dilakukan dengan cara observasi, studi kepustakaan dan wawancara. Hasil dari penelitian ini adalah mempermudah pihak kantor desa Bogoharjo dalam proses pengelolaan data penduduk, membantu dalam proses penginputan data, pencarian data, dan laporan penduduk.

4. Menurut Denna (STMIK Raharja, 2015/2016) dalam laporan SKRIPSI yang berjudul "Perancangan Sistem Pengolahan Data Penduduk Berbasis Web Pada Kantor Kelurahan Desa Tapos". 
5. Menurut Elin Herlian (STMIK Raharja, 2013/2014) dalam laporan SKRIPSI yang berjudul "Perancangan Sistem Informasi Data Kependudukan Pada Kelurahan KutaBaru Kabupaten Tangerang Berbasis Web".

6. Menurut Ahmad Zaeni (STMIK Raharja, 2013/2014) dalam laporan SKRIPSI yang berjudul "Perancangan Sistem Sensus Penduduk Untuk Memonitoring Populasi Pertumbuhan Penduduk Pada Desa Bojong Kecamatan Cikupa Kabupaten Tangerang".

Dari enam literature review dapat disimpulkan pula bahwa belum ada peneliti yang secara khusus membahas menegenai perancangan aplikasi system kependudukan desa berbasis web.

\section{HASIL DAN PEMBAHASAN}

Membangun aplikasi analisa Sistem Kependudukan Desa Berbasis Web Pada Desa Cihuni Kecamatan Pagedangan Kabupaten Tangerang yang mudah dioperasikan, cepat dan akurat.

1. Aplikasi analisa Sistem Kependudukan Desa Berbasis Web Pada Desa Cihuni Kecamatan Pagedangan Kabupaten Tangerang yang akan dibuat harus terintegrasi dengan database yang sudah dinormalisasi sehingga mencegah data-data yang ambigu.

2. Aplikasi analisa system Sistem Kependudukan Desa Berbasis Web Pada Desa Cihuni Kecamatan Pagedangan Kabupaten Tangerang yang akan dibuat disarankan dapat diakses oleh berbagai device dan gadget sehingga memudahkan Staff Pegawai Kelurahan untuk memonitor laporan analisa Sistem Kependudukan Desa Berbasis Web Pada Desa Cihuni Kecamatan Pagedangan Kabupaten Tangerang dimana saja dan kapan saja.

\subsection{Usecase Diagram Sistem Warga Yang Diusulkan}

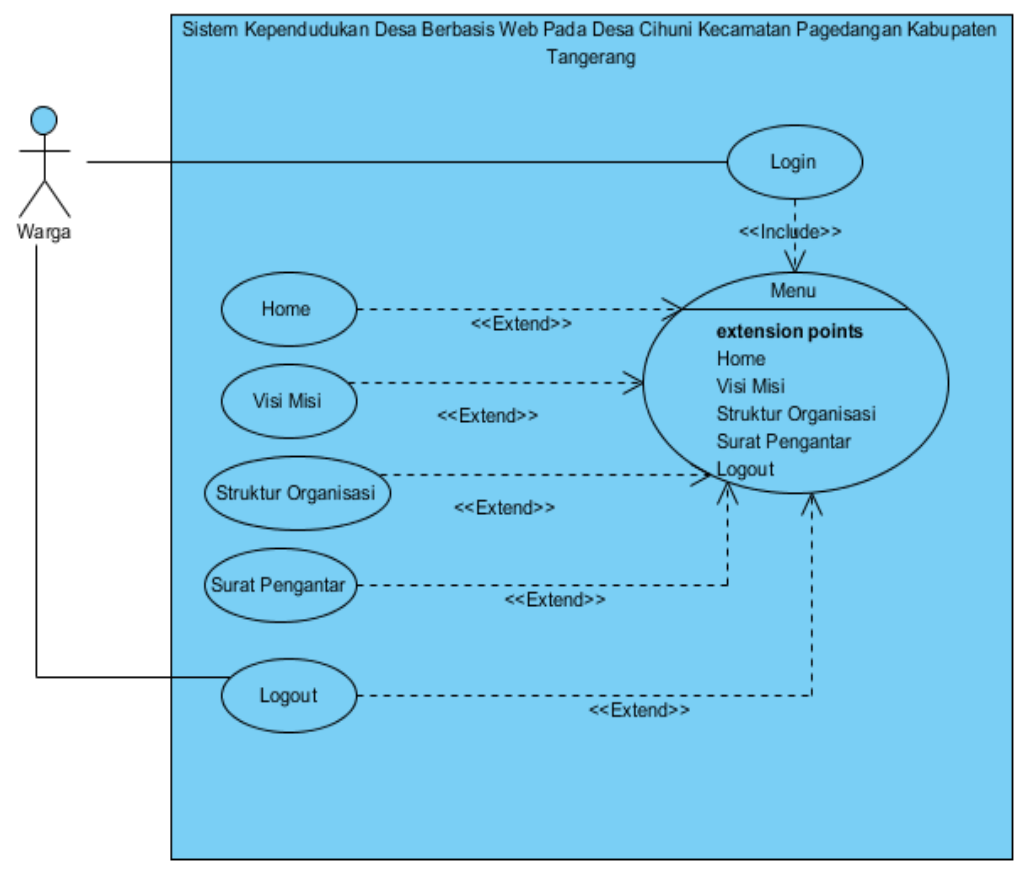

Gambar 2. Use Case Diagram Sistem Warga yang diusulkan

Tampak pada gambar dua merupakan system kependudukan desa berbasis web yang di usulkan terdapat:

1) 1 sistem yang mencangkup satu kegiatan yang sedang berjalan pada Kelurahan Desa Cihuni.

2) 1 actor yang melakukan kegiatan, yaitu : warga.

3) 7 use case yang dilakukan oleh 1 actor. 
4) 1 include yang meliputi login.

5) 5 extend yang meliputi home masuk ke menu, visi misi ke menu, struktur organisasi ke menu, surat pengantar ke menu,log out dari menu.

\subsection{Activity Diagram Sistem Warga Yang Diusulkan}

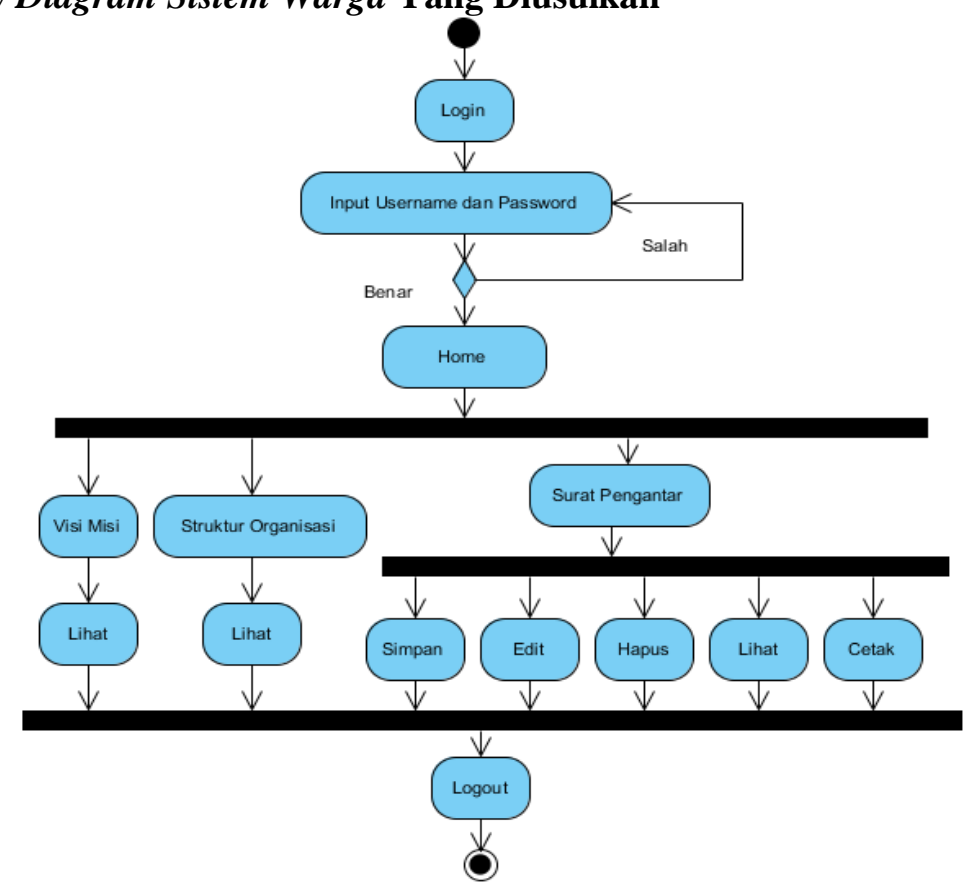

Gambar 3. Activity Diagram Sistem Warga yang diusulkan

Berdasarakan gambar 3 Activity Diagram Sistem Warga Yang Diusulkan yang berjalan diatas terdapat:

1) 1 Initial node sebagai awal objek.

2) 1 Decision Node untuk memecah aktivitas yang bersifat kondisional benar atau salah

3) 14 Action dari sistem yang mencerminkan eksekusi dari suatu aksi

4) 3 Fork untuk memecah behaviour menjadi aktivitas yang paralel

5) 1 Final Node sebagai objek yang diakhri.

\subsection{Sequence Diagram Sistem Warga yang diusulkan}

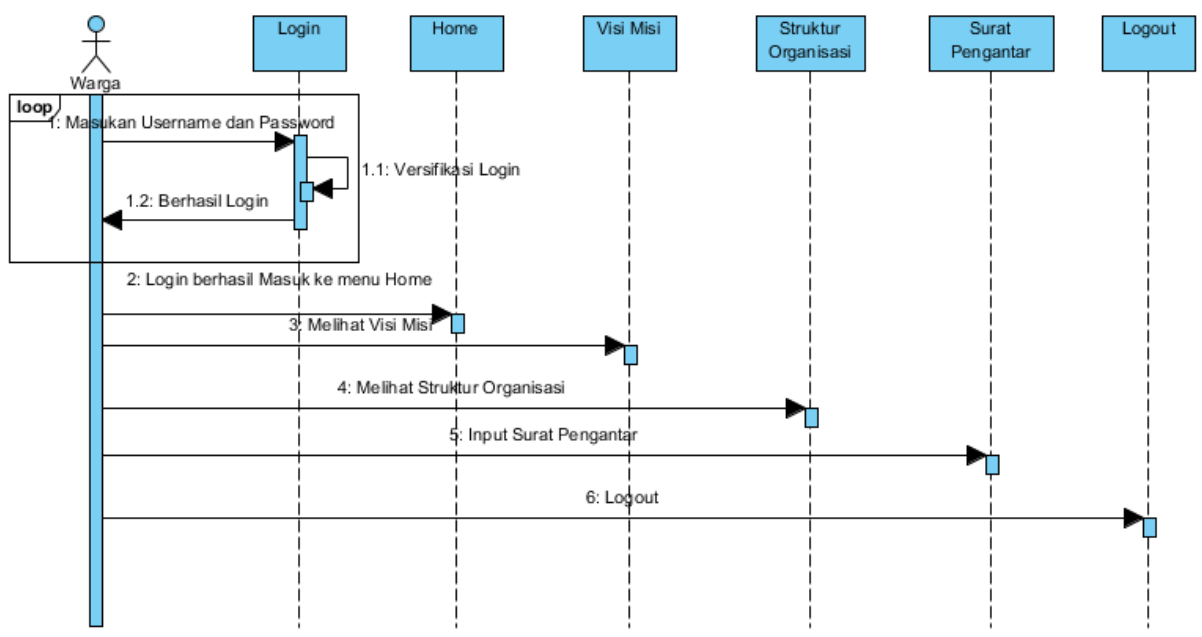

Gambar 4. Sequence Diagram Sistem Warga yang diusulkan 
Berdasarakan gambar 4 Sequence Diagram Sistem Warga yang berjalan diatas terdapat:

Sequence diagram diatas terdiri dari satu actor, yaitu warga. Warga

1. Masuk halaman login

2. Masukan user name dan password

3. Versifikasi

4. Login berhasil ke menu Home

5. Lihat Visi Misi

6. Lihat Struktur Organisasi

7. Input Surat Pengantar

8. Logout

Dan berikut ini adalah table daftar pertanyaan mengenai aplikasi sistem kependudukan desa berbasis web pada desa cihuni kecamatan pagedangan kabupaten tangerang.

Gambar 5. Table daftar pertanyaan

\begin{tabular}{|c|c|c|c|}
\hline No & Pertanyaan & Ya & Tidak \\
\hline 1 & $\begin{array}{l}\text { Apakah aplikasi sistem kependudukan desa berbasis web } \\
\text { pada desa cihuni kecamatan pagedangan kebupaten tangerang } \\
\text { mendukung proses yang sudah ada di kelurahan desa cihuni }\end{array}$ & $\mathrm{X}$ & \\
\hline 2 & $\begin{array}{l}\text { Apakah dengan adanya aplikasi sistem kependudukan desa } \\
\text { berbasis web pada desa cihuni kecamatan pagedangan } \\
\text { kebupaten tangerang dapat mempermudah proses pelayanan } \\
\text { surat pengantar. }\end{array}$ & $\mathrm{X}$ & \\
\hline 3 & $\begin{array}{l}\text { Sudah Sempurnakah aplikasi sistem kependudukan desa } \\
\text { berbasis web pada desa cihuni kecamatan pagedangan } \\
\text { kebupaten tangerang }\end{array}$ & & $X$ \\
\hline 4 & $\begin{array}{l}\text { Apakah dengan adanya aplikasi sistem kependudukan desa } \\
\text { berbasis web pada desa cihuni kecamatan pagedangan } \\
\text { kebupaten tangerang dapat mempermudah dalam Proses } \\
\text { pembuatan surat pengantar. }\end{array}$ & $\mathrm{X}$ & \\
\hline 5 & $\begin{array}{l}\text { Apakah dengan adanya aplikasi sistem kependudukan desa } \\
\text { berbasis web pada desa cihuni kecamatan pagedangan } \\
\text { kebupaten tangerang Proses Pelayanan Surat Pengantar } \\
\text { Menjadi Lebih Baik }\end{array}$ & $\mathrm{X}$ & \\
\hline
\end{tabular}

Berdasarkan pada daftar gambar 5 diatas, yaitu table daftar pertanyaan aplikasi sistem kependudukan desa berbasis web pada desa cihuni kecamatan pagedangan kabupaten tangerang di atas dapat bahwa dalam perancangan dan pembuatan aplikasi sistem kependudukan desa berbasis web pada desa cihuni kecamatan pagedangan kabupaten tangerang dapat mendukung dalam pelayanan surat pengantar dengan adanya aplikasi sistem kependudukan desa berbasis web pada desa cihuni kecamatan pagedangan kabupaten tangerang dapat mempermudah dan meningkatkan pelayanan menjadi lebih baik. aplikasi sistem kependudukan desa berbasis web pada desa cihuni kecamatan pagedangan kabupaten tangerang layak untuk di buat karena dapat mendukung pelayanan pembuatan surat pengantar .

Merupakan gambaran flowchart alur program yang berjalan dari aplikasi sistem kependudukan desa berbasis web pada desa cihuni kecamatan pagedangan kabupaten tangerang. 


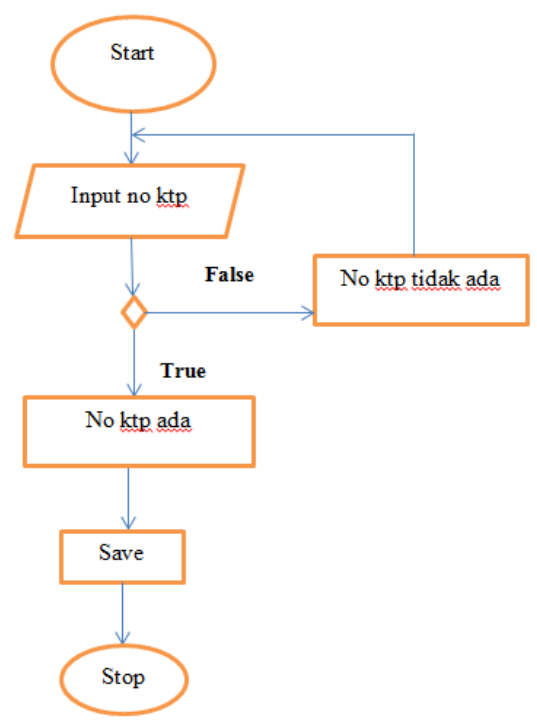

Gambar 6. Flowchart alur rancangan aplikasi.

Tampak pada gambar 6 diatas, merupakan flowchart rancangan aplikasi sistem kependudukan desa berbasis web pada desa cihuni kecamatan pagedangan kabupaten tangerang,dengan menggambarkan proses input no ktp pada program. Dimulai dari hal penginputan data lalu proses save.

\subsection{Listing Program}

aplikasi sistem kependudukan desa berbasis web pada desa cihuni kecamatan pagedangan kabupaten tangerang merupakan sebuah aplikasi media penyimpanan untuk membuat surat pengantar, sehingga listing program yang akan ditampilkan yaitu listing program untuk form surat pengantar contoh yang ada. Berikut listing programnya :

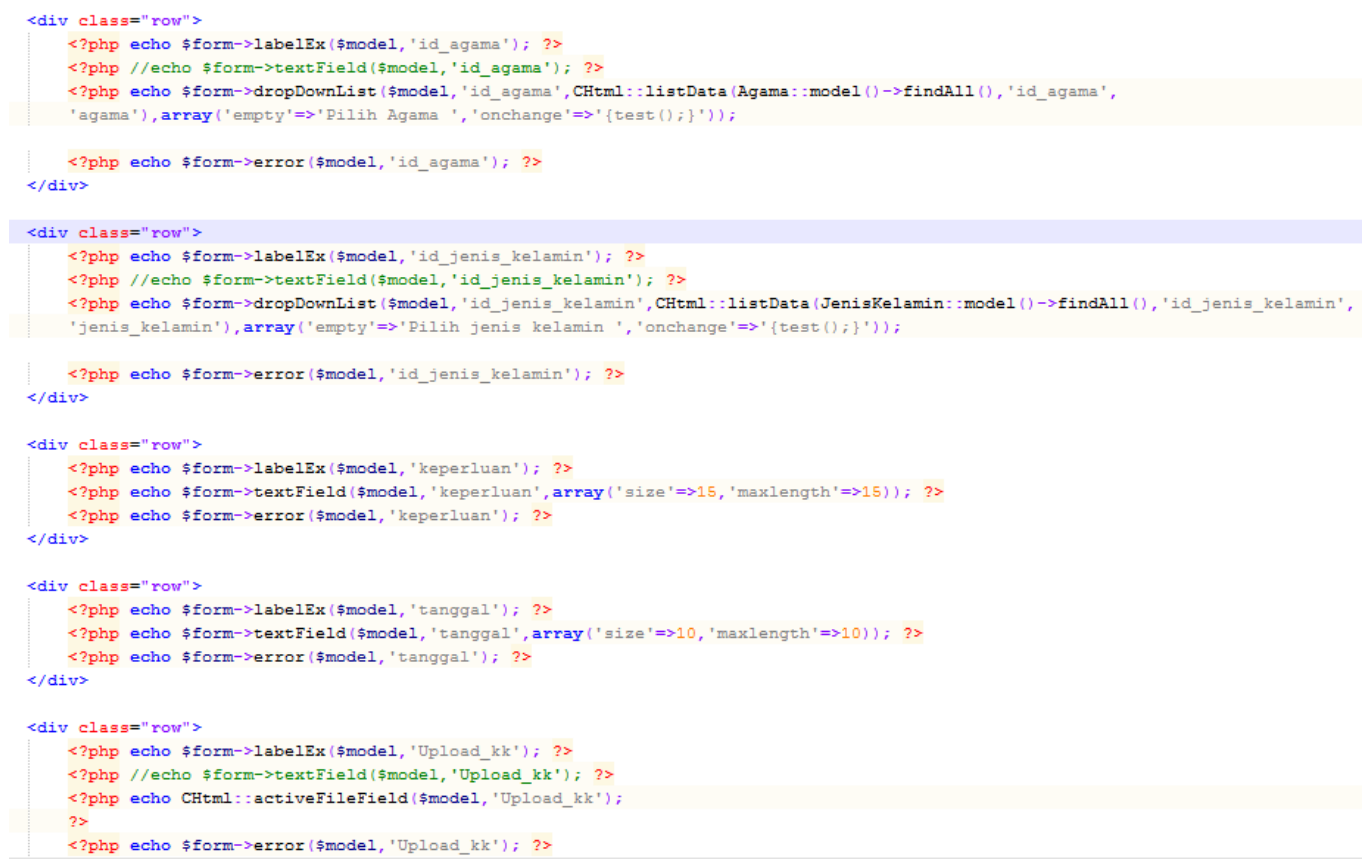

Gambar 7. Listing program surat pengantar 


\subsection{Implementasi}

Tampilan rancangan aplikasi sistem kependudukan desa berbasis web pada desa cihuni kecamatan pagedangan kabupaten tangerang.

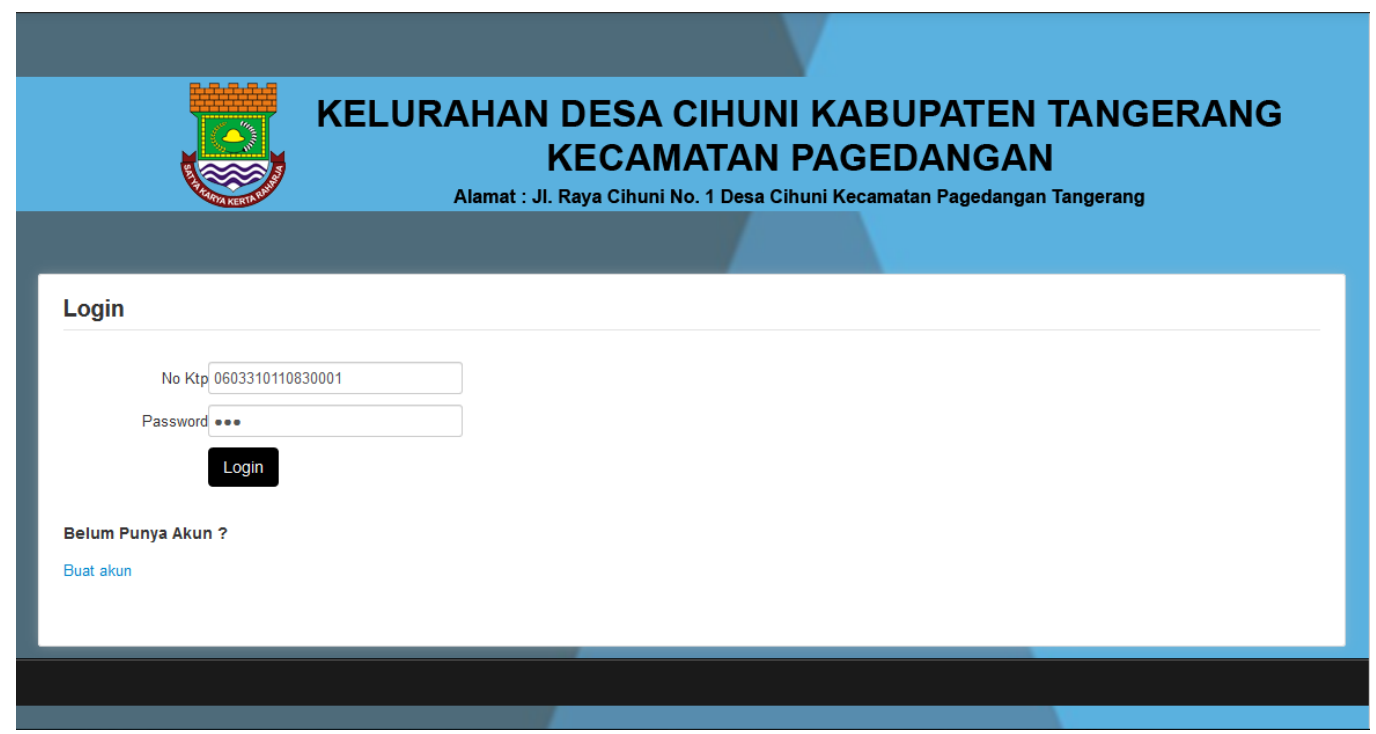

Gambar 8. Tampilan login

Tampak pada gambar diatas merupakan tampilan login yang digunakan untuk membuat rancangan aplikasi sistem kependudukan desa berbasis web pada desa cihuni kecamatan pagedangan kabupaten tangerang .

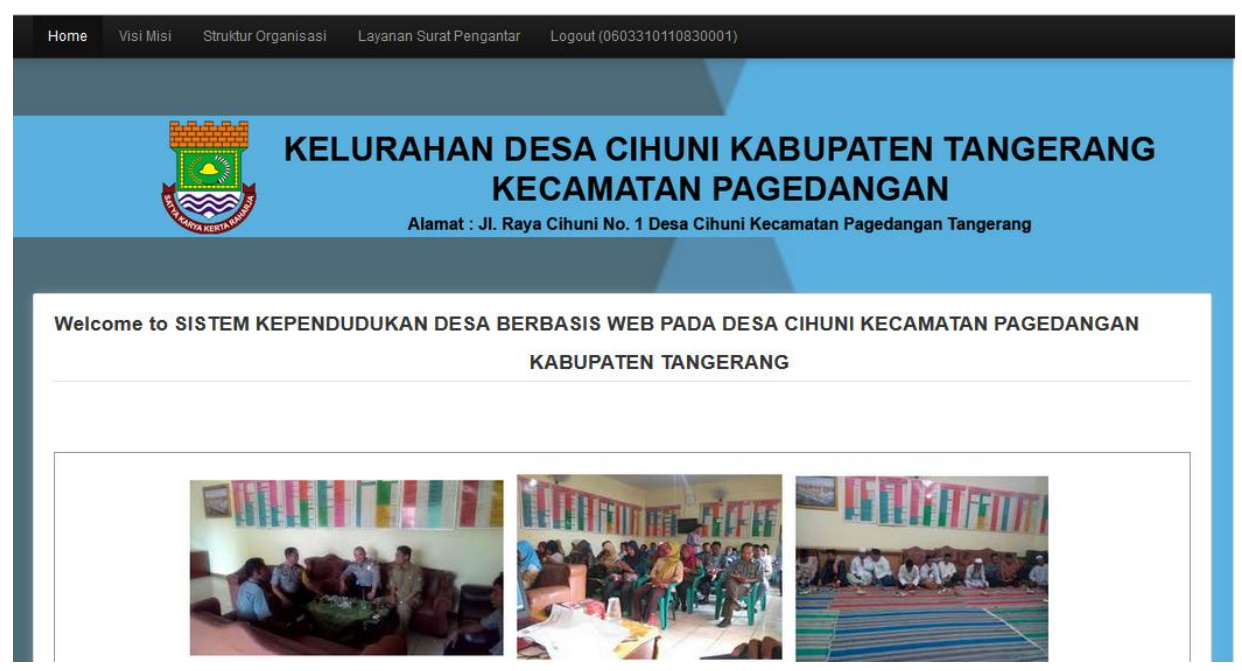

Gambar 9. Gambar tampilan home

Pada gambar diatas, merupakan gambar tampilan home 


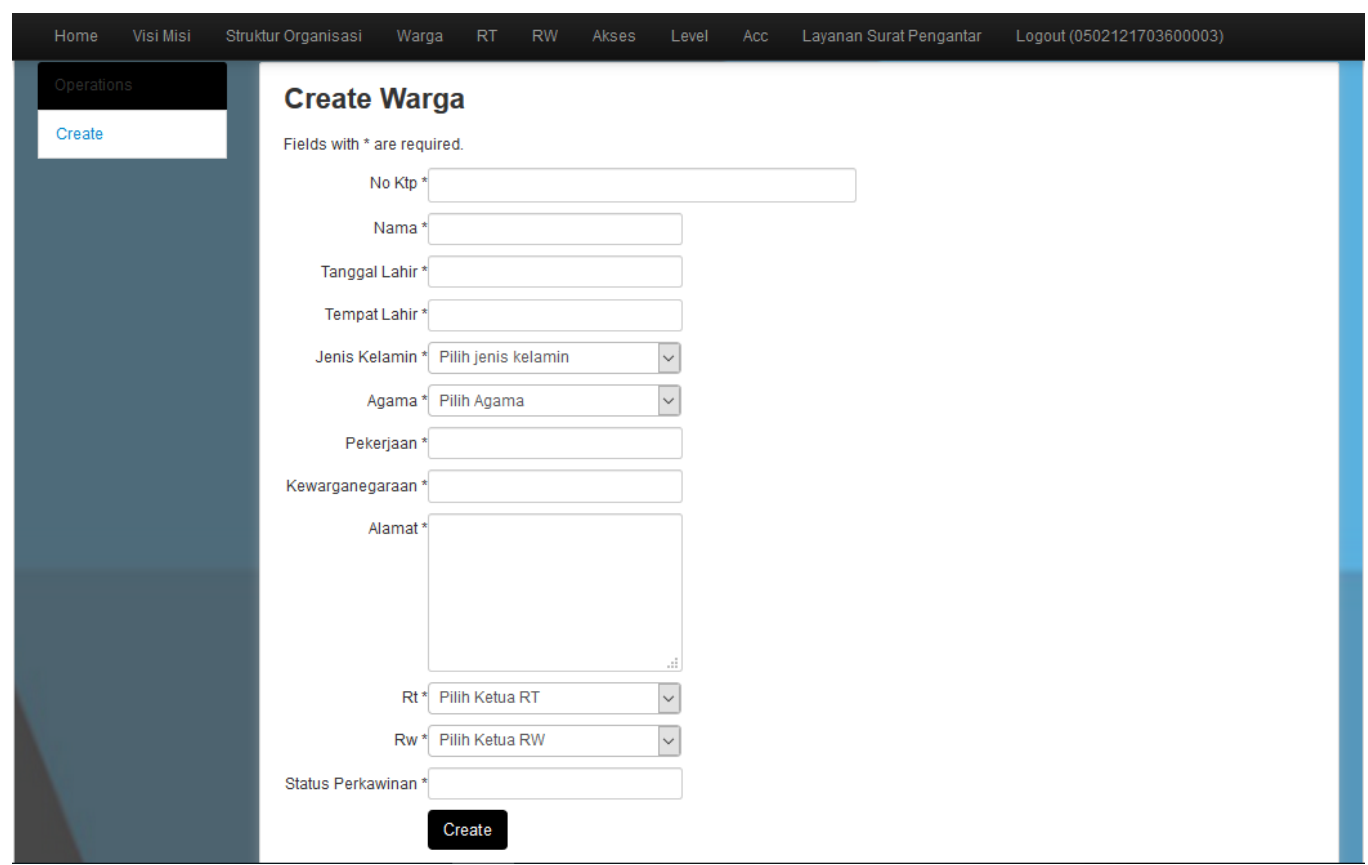

Gambar 10. Gambar tampilan create warga

Pada gambar diatas, merupakan gambar tampilan create warga

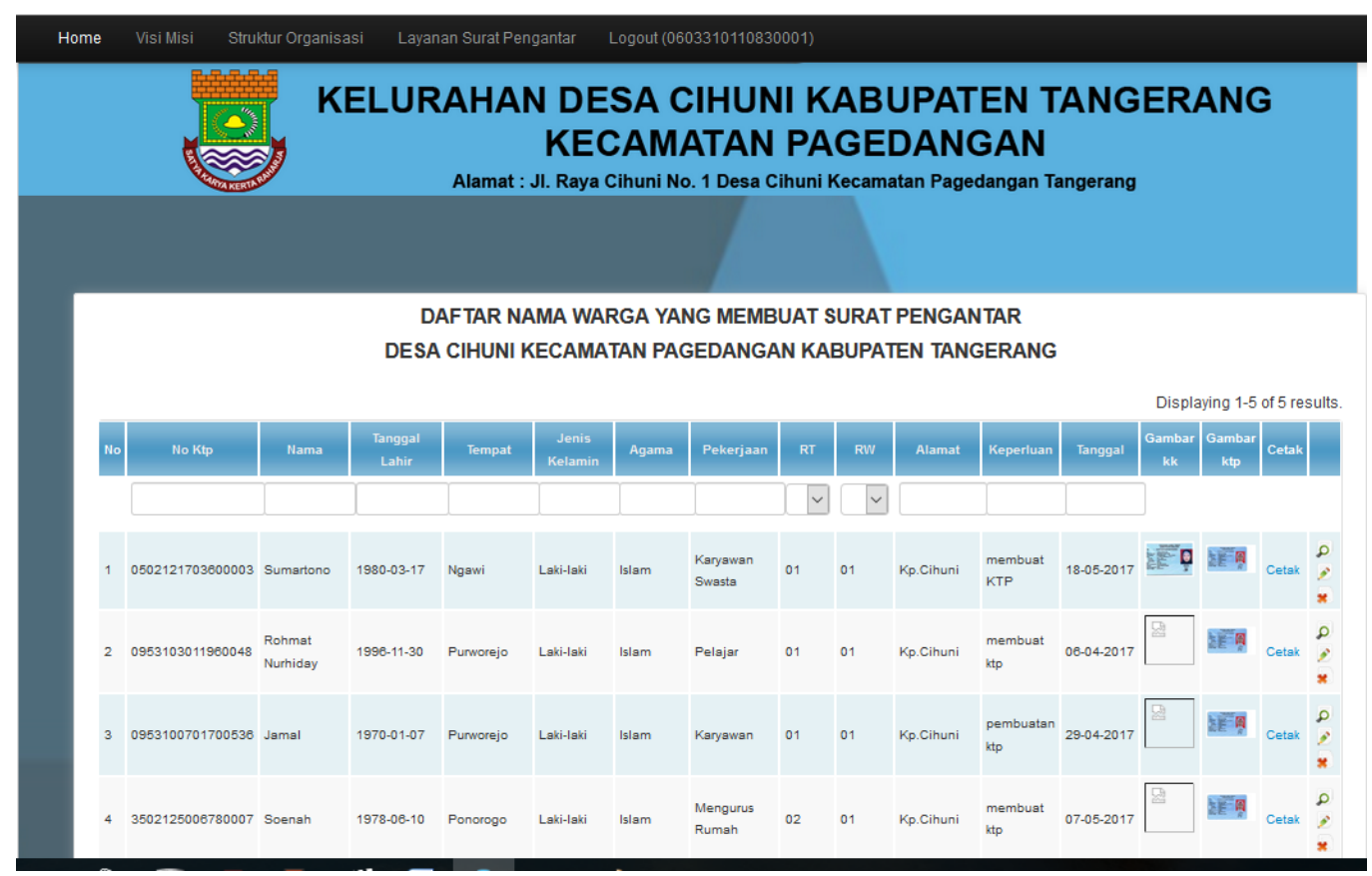

Gambar 11. Gambar tampilan admin warga

Pada gambar diatas, merupakan gambar tampilan admin warga 


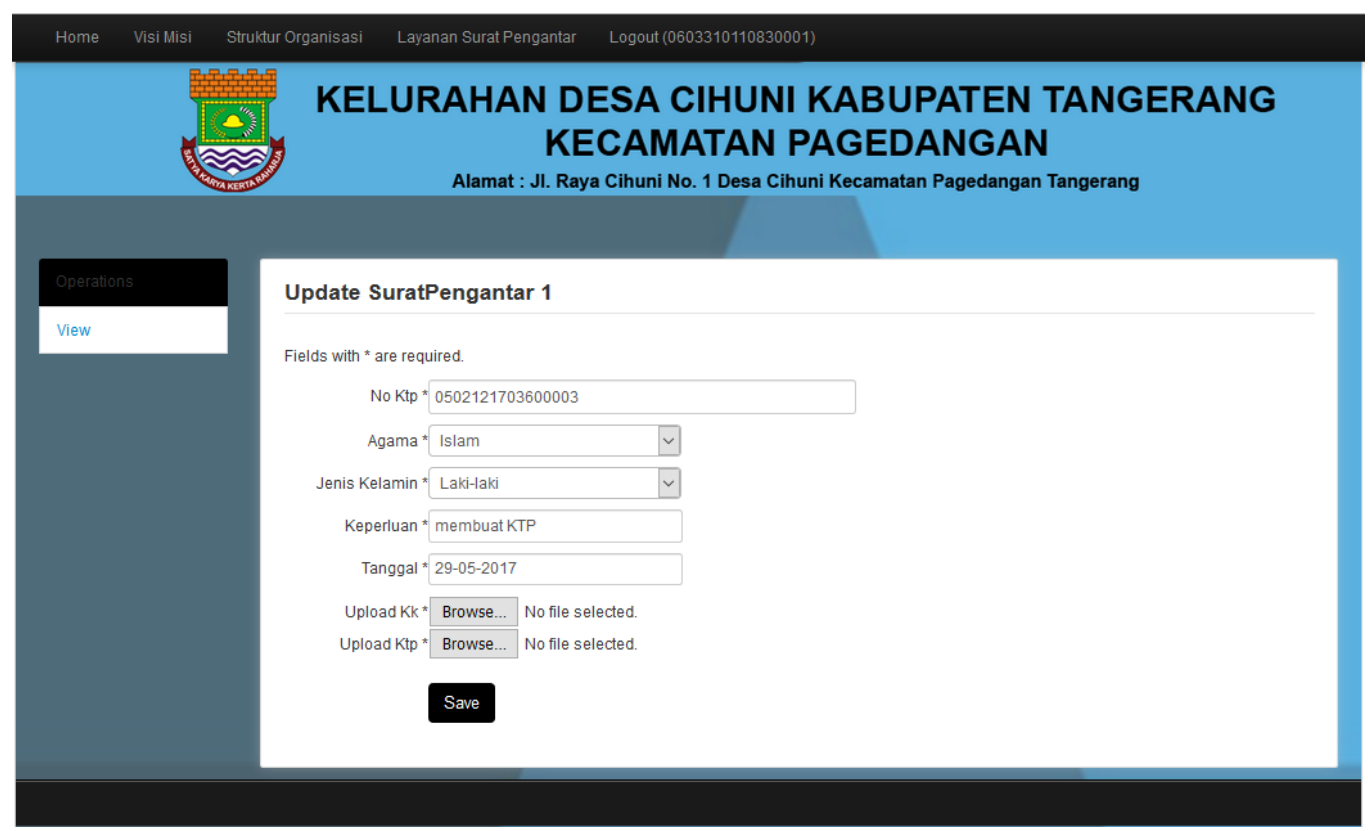

Gambar 12. Gambar tampilan Update surat pengantar

Pada gambar diatas, merupakan gambar tampilan update surat pengantar

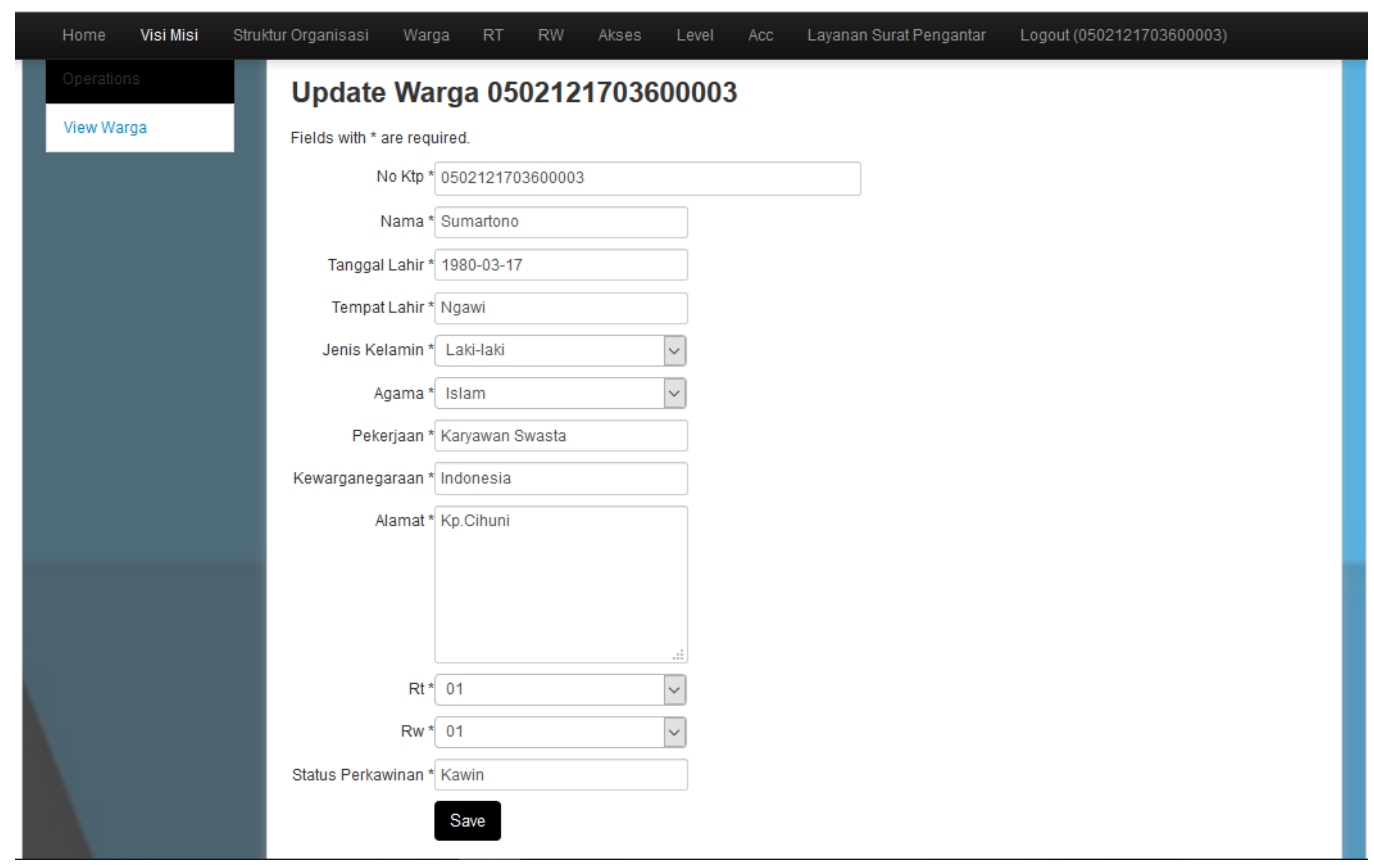

Gambar 13. Gambar tampilan update warga

Pada gambar diatas, merupakan gambar tampilan update warga

\section{KESIMPULAN DAN SARAN}

Dengan demikian, dapat disimpulkan bahwa penerapan Sistem Kependudukan Desa ini di Kelurahan Desa Cihuni akan dapat mendukung staf desa, khusunya dalam data kependudukan yang bermasalah dimana sistem yang sebelumnya masih bersifat manual atau dikerjakan secara tertulis serta staf desa tidak perlu mengeprint data kependudukan. Dilihat 
dari segi keamanannya sudah baik, karena setiap user sudah diberikan hak akses sesuai dengan kebutuhannya masing-masing.

\section{DAFTAR PUSTAKA}

[1] Rusdiana, HA., dan Moch Irfan.2014. "Sistem Informasi Manajemen”. Bandung:Pustaka Setia.ISBN: 978-9790764217.

[2] Suprihadi, Hudiono, Rini. Kartika, Wijaya. Lina. Sinatra 2013. "Rancang Bangun Sistem Jejaring Klaster Berbasis Web Menggunakan Metode Model View Controller". Tangerang: STMIK Raharja. Jurnal CCIT Vol. 6 No. 3, Mei 2013 ISSN: 1978-8282.

[3] Sutabri, Tata.2014."konsep sistem informasi".'Yogyakarta:Andi offset.

[4] Yakub. 2012."Pengantar Sistem Informasi". Yogyakarta: Graha ilmu.

[4] rochman, abdur, hilmi fuad, ebi muhibin.2015."sistem informasi kinerja dosen pada universitas kejuangan '45".STIMIK Bina sarana global.jurnal sisfoktek global.vol.5 no.1 maret 2015.ISNN: 2088-1762.

[5] Warsito. Ary. Budi, Yusup. Muhamad, Makaram. Moh. Iqbal. Awi. 2015. "Perancangan SiS+ Menggunakan metode YII Framework Pada Perguruan Tinggi Raharja". Tangerang: Perguruan Tinggi Raharja. Jurnal CCIT. Vol. 8 No. 2, Januari 2015 ISSN : $1978-8282$.

[6] Vani. M. L. V. Roopa, Kumari. M. Chandrika, Priya. M. Hari, Harika. N. 2015. "An Effective Language for Object Oriented Design-UML(Unified Modeling Language)". India:Institute of Engineering \& Technology. International Research Journal of Engineering and Technology (IRJET) Vol. 2 No. 5, Agustus 2015 ISSN: 2395-0056.

[7] Murad. Dina. Fitria, Kusniawati. Nia, Asyanto. Agus. 2013. "Aplikasi Intelligence Website Untuk Penunjang Laporan PAUD Pada Himpaudi Kota Tangerang". Tangerang: Perguruan Tinggi Raharja. Jurnal CCIT. Vol. 7 No. 1, September 2013 ISSN: 1978 8282.

[8] Indrajani. 2015. "Database Design". Jakarta: PT Elex Media Komputindo.

[9] Qader, Akram. Abdel, Musa. Khaled. 2013. "Distributed Graphical User Interfaces to ClassDiagram Reverse Engineering Approach usingPattern Recognition". Jordan : AlZaytoonah University of Jordan. International Journal of Software Engineering \& Applications (IJSEA), Vol. 4 No. 3, May 2013.

[10] Komputer,Wahana.2013. "Mobile Web Development With Adobe DreamweaverCS6".Yogyakarta:Andi offset.

[11] Sidiq, Betha.2014. "Pemrograman Web PHP".Edisi Revisi ke-2 Cetakan ke-1,Bandung: Informatika Bandung 